\title{
PENGARUH PEMBANGUNAN SUMBER DAYA MANUSIA DAN PERTUMBUHAN EKONOMI TERHADAP TINGKAT KEMISKINAN DI INDONESIA
}

(Dengan Kewilayahan Sebagai Variabel Moderasi)

\author{
Wawan Kurniawan, S.ST \\ Aparatur Sipil Negara Kabupaten Sragen \\ Email : wankur45@gmail.com
}

\begin{abstract}
This study aims to determine the direction and strength of the influence of human resource development and economic growth simultaneously and partially to the level of poverty in Indonesia, to determine the difference of poverty level in Indonesia based on Java and Outer Territories, to determine the effect of human resource development and economic growth on the level of poverty in Indonesia based on Javanese and Outer Territories, as well as to know the effect of human resource development and economic growth on poverty level in Indonesia based on regional economic structure difference. This study was designed as a quantitative study with provincial analysis unit in Indonesia, using panel data of 33 provinces in 2009-2013. Analyzer used in this research is multiple regression analysis. The results of the analysis show that human resource development significantly plays a role in reducing the poverty rate in Indonesia, while the economic growth moves in line with the level of poverty; Indonesia's poverty rate that is influenced by human resource development and economic growth does not differ significantly between Java and Outer Java, the influence of human resource development and economic growth on poverty level in Indonesia differs between Java and Outer Java; The economic structure of a region does not affect the poverty level in Indonesia.
\end{abstract}

\section{Keywords: Poverty, Economic Growth, Human Development}

\begin{abstract}
ABSTRAK
Penelitian ini bertujuan untuk mengetahui arah dan kuatnya pengaruh pembangunan SDM dan pertumbuhan ekonomi secara simultan dan parsial terhadap tingkat kemiskinan di Indonesia, untuk mengetahui perbedaan tingkat kemiskinan di Indonesia berdasarkan kewilayahan Jawa dan Luar Jawa, untuk mengetahui pengaruh pembangunan SDM dan pertumbuhan ekonomi terhadap tingkat kemiskinan di Indonesia berdasarkan kewilayahan Jawa dan Luar Jawa, serta untuk mengetahui pengaruh pembangunan SDM dan pertumbuhan ekonomi terhadap tingkat kemiskinan di Indonesia berdasarkan perbedaan struktur ekonomi wilayah. Penelitian ini dirancang sebagai penelitian kuantitatif dengan unit analisis provinsi di Indonesia, menggunakan data panel 33 provinsi tahun 2009-2013. Alat analisis yang digunakan dalam penelitian ini adalah analisis regresi berganda. Hasil analisis menunjukkan: pembangunan SDM secara signifikan berperan dalam menurunkan tingkat kemiskinan di Indonesia, sedangkan pertumbuhan ekonomi bergerak searah dengan tingkat kemiskinan; tingkat kemiskinan Indonesia yang dipengaruhi oleh pembangunan SDM dan pertumbuhan ekonomi tidak berbeda secara signifikan antara Jawa dengan Luar Jawa;pengaruh pembangunan SDM dan pertumbuhan
\end{abstract}


ekonomi terhadap tingkat kemiskinan di Indonesia berbeda antara wilayah Jawa dengan Luar Jawa; perbedaan struktur perekonomian suatu wilayah tidak berpengaruh terhadap tingkat kemiskinan di Indonesia.

\section{Kata kunci : Kemiskinan, Pertumbuhan Ekonomi, Pembangunan Manusia}

\section{Pendahuluan}

Pertumbuhan ekonomi Indonesia periode 2009-2013 mencapai rata-rata 5,9 persen per tahun yang merupakan pertumbuhan ekonomi tertinggi setelah krisis ekonomi lima belas tahun lalu. Data yang lain mencatat selama Januari-April 2014, ada peningkatan 9,7 persen cadangan devisa, dengan posisi pada saat itu sebesar USD 105,6 miliar.Di balik tingginya laju pertumbuhan ekonomi tersebut, menurut data Badan Pusat Statistik, Indonesia masih memiliki 28,5 juta jiwa (11,47 persen) yang hidup di bawah garis kemiskinan pada September 2013.

Kemiskinan di Indonesia merupakan salah satu penyakit dalam ekonomi, sehingga harus disembuhkan atau paling tidak dikurangi. Permasalahan kemiskinan memang merupakan permasalahan yang kompleks dan bersifat multidimensional. Oleh karena itu, upaya pengentasan kemiskinan harus dilakukan secara komprehensif, mencakup berbagai aspek kehidupan masyarakat, dan dilaksanakan secara terpadu. Istilah kemiskinan muncul ketika seseorang atau sekelompok orang tidak mampu mencukupi tingkat kemakmuran ekonomi yang dianggap sebagai kebutuhan minimal dari standar hidup tertentu. Kemiskinan disebabkan oleh berbagai faktor, di antaranya kualitas pembangunan manusia yang rendah, pertumbuhan ekonomi yang semu, dan kesenjangan/disparitas antar wilayah.

Kualitas sumber daya manusia dapat dilihat dari indeks kualitas hidup atau Indeks Pembangunan Manusia (IPM). Rendahnya IPM akan berakibat pada rendahnya produktivitas kerja dari penduduk. Produktivitas yang rendah berakibat pada rendahnya perolehan pendapatan. Rendahnya pendapatan menyebabkan tingginya jumlah penduduk miskin, sehingga rendahnya kualitas sumber daya manusia merupakan salah satu faktor penyebab terjadinya penduduk miskin.

Gambar 1.2. Perkembangan Indeks Pembangunan Manusia (IPM) Indonesia Tahun 2009-2013 


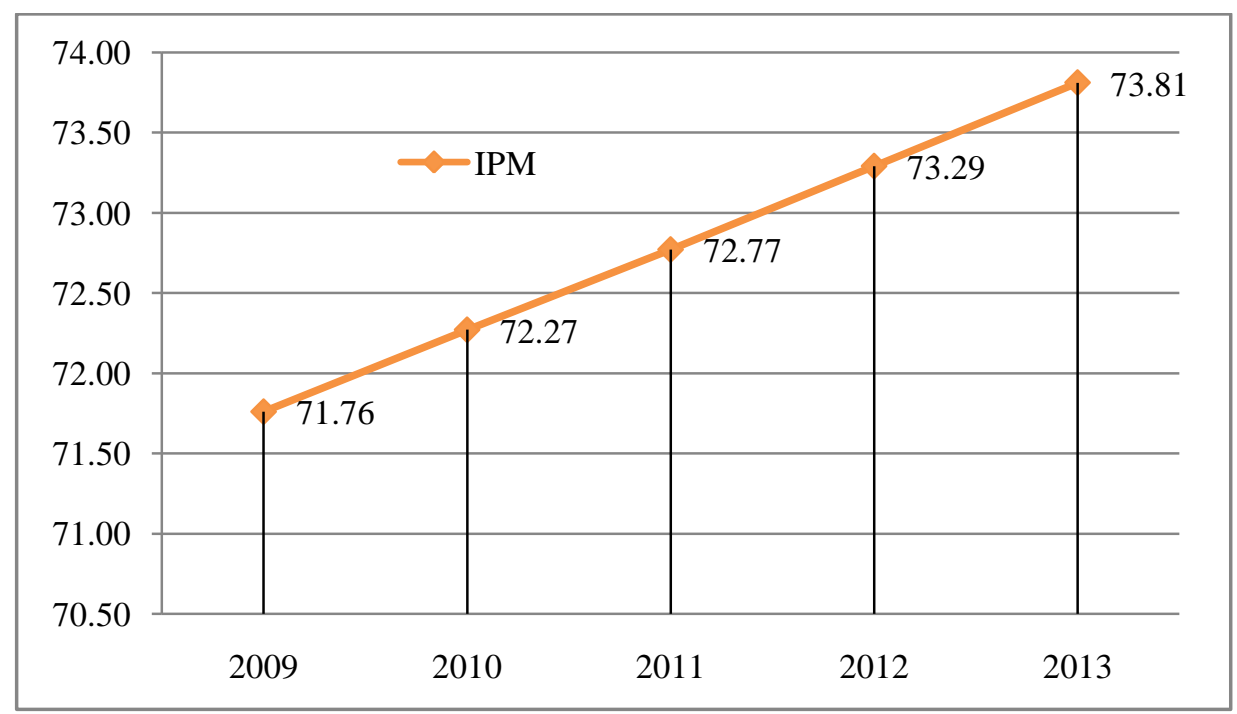

Sumber : Diolah dari BPS, http://bps.go.id/, 2015

Lanjouw, dkk. (2011) menyatakan pembangunan manusia di Indonesia adalah identik dengan pengurangan kemiskinan. Investasi di bidang pendidikan dan kesehatan akan lebih berarti bagi penduduk miskin dibandingkan penduduk tidak miskin, karena bagi penduduk miskin aset utama adalah tenaga kasar mereka. Adanya fasilitas pendidikan dan kesehatan murah akan sangat membantu untuk meningkatkan produktivitas, dan pada gilirannya meningkatkan pendapatan.

Pertumbuhan ekonomi suatu negara dapat dikatakan berhasil apabila laju pertumbuhan PDB lebih tinggi dari laju pertumbuhan penduduk negara yang bersangkutan. Dengan demikian, pertumbuhan ekonomi tersebut akan lebih bermakna pada kehidupan masyarakat. Berdasarkan pada kaitan kedua konsep ekonomi ini pada hakekat pembangunan ekonomi adalah untuk menaikan tingkat kehidupan masyarakat melalui peningkatan produktifitas perkapita, investasi sumber daya manusia, investasi fisik dan kesempatan kerja (Mishkin, 2012 dalam Aimon, 2012:209-210).

Menurut Sukirno (2000), laju pertumbuhan ekonomi adalah kenaikan PDRB tanpa memandang apakah kenaikan itu lebih besar atau lebih kecil. Selanjutnya pembangunan ekonomi tidak semata-mata diukur berdasarkan pertumbuhan produk domestik regional bruto (PDRB) secara keseluruhan, tetapi harus memperhatikan sejauh mana distribusi pendapatan telah menyebar kelapisan masyarakat serta siapa yang telah menikmati hasil-hasilnya. Menurunnya PDRB berdampak pada kualitas konsumsi rumah tangga. Apabila tingkat pendapatan penduduk sangat terbatas, banyak rumah tangga miskin terpaksa mengubah pola makanan pokoknya ke barang paling murah dengan jumlah barang yang berkurang.

Kesenjangan/disparitas pembangunan antar wilayah di Indonesia juga menjadi penyebab masih tingginya kemiskinan. Fenomena disparitas di Indonesia terjadi antar wilayah Jawa-Luar Jawa, kawasan barat Indonesia (KBI)-kawasan timur Indonesia (KTI), antar pulau/kepulauan, antar wilayah berdasarkan basis 
perekonomian, dan lain-lain. Disparitas tersebut terjadi karena perbedaan sumber daya yang dimiliki, baik sumber daya alam, sumber daya manusia maupun sumber daya lainnya. Disparitas antar wilayah memang tidak mungkin dihilangkan, tapi minimal bisa dikurangi.

Gambar 1.3. Kontribusi Enam Kelompok Wilayah dalam Pembentukan PDB Nasional Tahun 2013

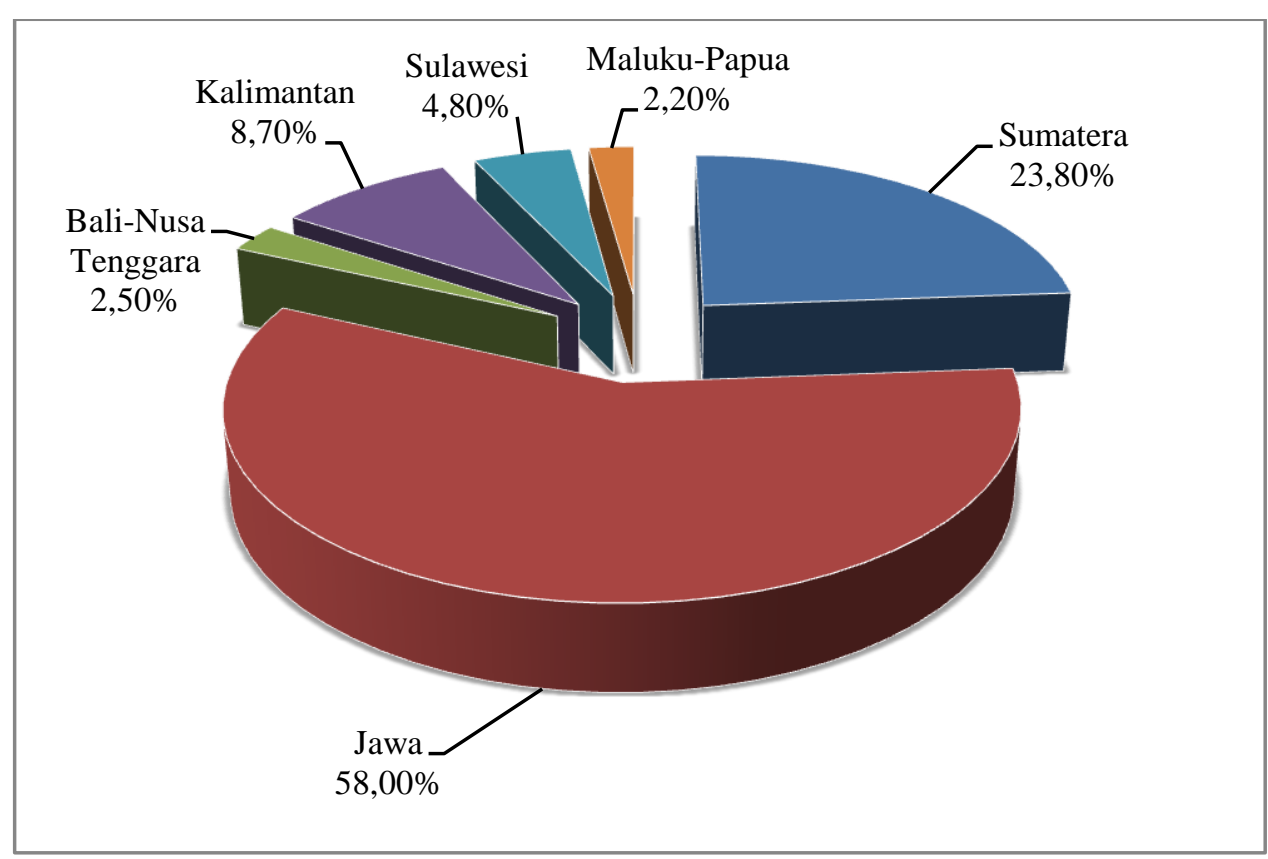

Sumber : Diolah dari Bappenas, 2015

Disparitas antar wilayah sangat terlihat pada kontribusi masing-masing wilayah dalam pembentukan PDB Nasional. Dalam Buku III RPJMN 2015-2019 halaman 1-15 yang dipublikasikan oleh Bappenas tercatat persentase kontribusi per wilayah dalam pembentukan PDB Nasional tahun 2013 sebagai berikut: Sumatera 23,8\%; Jawa 58,0\%; Bali-Nusa Tenggara 2,5\%; Kalimantan 8,7\%; Sulawesi 4,8\%; Maluku-Papua 2,2\%, seperti terlihat dalam Gambar 1.3. Disparitas tersebut tentu saja mempengaruhi kemampuan masing-masing wilayah dalam mengentaskan kemiskinan. Selain itu, disparitas yang ada akan mempengaruhi pembangunan kualitas manusia pada masing-masing wilayah. Program kegiatan dalam pengentasan kemiskinan antar wilayah di Indonesia seharusnya tidak disama-ratakan karena harus memperhatikan kewilayahan.

Disparitas wilayah secara nyata telah memperlihatkan perbedaan kemampuan daerah dalam membangun sumber daya manusia dan perekonomiannya yang pada akhinya berpengaruh pada perbedaan kemampuan dalam pengentasan kemiskinan. Hal tersebut yang membuat penulis tertarik untuk mengkaji sejauh mana pengaruh pembangunan sumber daya manusia dan pertumbuhan ekonomi terhadap tingkat kemiskinan berdasarkan kewilayahan di Indonesia. 


\section{PERUMUSAN MASALAH}

Permasalahan dalam penelitian ini adalah pada periode tahun 2009-2013 pertumbuhan ekonomi Indonesia dalam kondisi yang baik dan tercatat sebagai pertumbuhan ekonomi tertinggi pasca krisis ekonomi tahun 1999. Selain itu, pembangunan manusia di Indonesia pada periode yang sama juga berkembang baik, dibuktikan dengan skor IPM yang selalu mengalami kenaikan setiap tahun. Di balik baiknya perekonomian dan pekembangan kualitas manusia tersebut, masih terdapat problematika tingkat kemiskinan yang tinggi di Indonesia. Walaupun tingkat kemiskinan di Indonesia pada periode tersebut selalu mengalami penurunan tetapi penurunan tersebut terlihat belum signifikan dan tingkat kemiskinan di Indonesia masih tergolong tinggi.

Indonesia mempunyai wilayah yang sangat luas dan berpulau-pulau dengan sumber daya alam, sumber daya manusia dan kondisi perekonomian yang berbedabeda. Ketidakmerataan pembangunan selama ini menjadikan disparitas wilayah semakin lebar. Hal tersebut berpengaruh pada kualitas manusia dan perkembangan ekonomi pada masing-masing wilayah yang pada akhirnya akan berdampak dalam proses penanggulangan kemiskinan. Sebenarnya telah banyak program yang digulirkan pemerintah baik pusat maupun daerah dalam menangani kemiskinan, tetapi penurunan kemiskinan tidak terlalu signifikan. Kebijakan dalam penanganan kemiskinan perlu memperhatikan faktor kewilayahan agar kebijakan dapat tepat sasaran sesuai dengan kondisi masing-masing wilayah.

Penelitian ini bertujuan untuk mengkaji arah dan kuatnya pengaruh pembangunan SDM dan pertumbuhan ekonomi secara simultan dan parsial terhadap tingkat kemiskinan di Indonesia; mengkaji perbedaan tingkat kemiskinan di Indonesia berdasarkan kewilayahan Jawa dan Luar Jawa; mengkaji pengaruh pembangunan SDM dan pertumbuhan ekonomi terhadap tingkat kemiskinan di Indonesia berdasarkan kewilayahan Jawa dan Luar Jawa; mengkaji pengaruh pembangunan SDM dan pertumbuhan ekonomi terhadap tingkat kemiskinan di Indonesia berdasarkan perbedaan struktur ekonomi wilayah.

Hasil penelitian ini diharapkan dapat memberikan manfaat untuk menjelaskan keterkaitan antara pembangunan sumber daya manusia dan pertumbuhan ekonomi dengan tingkat kemiskinan di Indonesia. Lebih jauh lagi, penelitian ini diharapkan mampu menjelaskan perbandingan pengaruh pembangunan sumber daya manusia dan pertumbuhan ekonomi terhadap tingkat kemiskinan yang berdasarkan kewilayahan, dalam penelitian ini disparitas kewilayahan yang diteliti adalah wilayah Jawa dengan Luar Jawa dan wilayah yang terbagi berdasarkan sektor perekonomian paling dominan. Penggunaan variabel kewilayahan merupakan kontribusi yang baru dari penelitian ini. 


\section{TINJAUAN PUSTAKA}

Kemiskinan adalah keadaan dimana terjadi kekurangan hal-hal yang biasa untuk dipunyai seperti makanan, pakaian, tempat berlindung dan air minum, hal ini berhubungan erat dengan kualitas hidup. Kemiskinan kadang juga berarti tidak adanya akses terhadap pendidikan dan pekerjaan yang mampu mengatasi masalah kemiskinan dan mendapatkan kehormatan yang layak sebagai warga negara (Wikipedia).

Kemiskinan dipahami sebagai keadaan kekurangan uang dan barang untuk menjamin kelangsungan hidup. Dalam arti luas, (Nasikun, 2001 dalam Suryawati, 2005:122) mengatakan bahwa kemiskinan adalah suatu intergrated concept yang memiliki lima dimensi, yaitu: a) kemiskinan, b) ketidakberdayaan, c) kerentanan menghadapi situasi darurat, d) ketergantungan, dan e) keterasingan baik secara geografis maupun sosiologis. Hidup dalam kemiskinan bukan hanya hidup dalam kekurangan uang dan tingkat pendapatan rendah, tetapi juga banyak hal lain, seperti: tingkat kesehatan, pendidikan rendah, perlakuan tidak adil dalam hukum, kerentanan terhadap ancaman tindak kriminal, ketidakberdayaan menghadapi kekuasaan, dan ketidakberdayaan dalam menentukan jalan hidupnya sendiri.

Indeks pembangunan manusia merupakan salah satu alat ukur yang dapat digunakan untuk menilai kualitas pembangunan sumber daya manusia, baik dari sisi dampaknya terhadap kondisi fisik manusia (kesehatan dan kesejahteraan) maupun yang bersifat non-fisik (intelektualitas). Pembangunan yang berdampak pada kondisi fisik masyarakat tercermin dalam angka harapan hidup serta kemampuan daya beli, sedangkan dampak non-fisik dilihat dari kualitas pendidikan masyarakat.

Indeks pembangunan manusia merupakan indikator strategis yang banyak digunakan untuk melihat upaya dan kinerja program pembangunan secara menyeluruh di suatu wilayah. Dalam hal ini IPM dianggap sebagai gambaran dari hasil program pembangunan yang telah dilakukan beberapa tahun sebelumnya. Demikian juga kemajuan program pembangunan dalam suatu periode dapat diukur dan ditunjukkan oleh besaran IPM pada awal dan akhir periode tersebut. IPM merupakan ukuran untuk melihat dampak kinerja pembangunan wilayah yang mempunyai dimensi yang sangat luas, karena memperlihatkan kualitas penduduk suatu wilayah dalam hal harapan hidup, intelelektualitas dan standar hidup layak.

Menurut Badan Pusat Statistik (BPS), PDRB pada dasarnya merupakan jumlah nilai tambah yang dihasilkan oleh seluruh unit usaha dalam suatu daerah tertentu, atau merupakan jumlah nilai barang dan jasa akhir yang dihasilkan oleh seluruh unit ekonomi pada suatu daerah. PDRB atas dasar harga berlaku menggambarkan nilai tambah barang dan jasa yang dihitung menggunakan harga pada tahun berjalan, sedang PDRB atas dasar harga konstan menunjukkan nilai tambah barang dan jasa 
tersebut yang dihitung menggunakan harga yang berlaku pada satu tahun tertentu sebagai tahun dasar. PDRB menurut harga berlaku digunakan untuk mengetahui kemampuan sumber daya ekonomi, pergeseran, dan struktur ekonomi suatu daerah. Sementara itu, PDRB konstan digunakan untuk mengetahui pertumbuhan ekonomi secara riil dari tahun ke tahun atau pertumbuhan ekonomi yang tidak dipengaruhi oleh faktor harga.

Menurut Sukirno (1996:33), pertumbuhan ekonomi ialah proses kenaikan output per kapita yang terus menerus dalam jangka panjang. Pertumbuhan ekonomi tersebut merupakan salah satu indikator keberhasilan pembangunan. Dengan demikian makin tingginya pertumbuhan ekonomi biasanya makin tinggi pula kesejahteraan masyarakat, meskipun terdapat indikator yang lain yaitu distribusi pendapatan.

Pembangunan ekonomi daerah merupakan proses pemerintah daerah dan masyarakat daerah mengelola sumber-sumber daya yang ada dan membentuk suatu pola kemitraan antara pemerintah daerah dengan sektor swasta untuk menciptakan lapangan kerja baru dan untuk mendorong perkembangan kegiatan ekonomi (pertumbuhan ekonomi) dalam suatu wilayah tertentu (Arsyad, 1999).

Indonesia memiliki wilayah geografis yang sangat luas dan berpulau-pulau. Terbentang mulai dari pulau Sabang di ujung barat pulau Sumatra sampai Merauke di pulau Papua. Dari pulau Miangas di utara sampai pulau Rote di selatan. Kondisi ini tentu saja mendatangkan kerumitan tersendiri dalam membangun. Selama ini pembangunan masih terpusat di Pulau Jawa dan sekitarnya, sehingga terjadi disparitas pembangunan yang menyebabkan perbedaan kemajuan antar wilayah. Wilayah yang semakin jauh dari pusat ibukota seolah-olah semakin kurang tersentuh pembangunannya, sehingga kekayaan alam yang banyak tersebar di seluruh pulau di Indonesia belum termanfaatkan dengan baik, bahkan ironisnya malah dimanfaatkan oleh negara asing. Sebab itulah sehingga mulai dalam penyusunan Rencana Pembangunan Jangka Menengah Nasional (RPJMN) 2010-2014, aspek kewilayahan ini dijadikan pertimbangan yang utama.

Dalam penelitian ini pembagian kewilayahan yang akan digunakan adalah Jawa - Luar Jawa dan kewilayahan berdasarkan perbedaan struktur ekonomi wilayah. Salah satu masalah nasional yang tak kunjung terselesaikan hingga saat ini adalah ketimpangan distribusi pembangunan antar wilayah, khususnya antara Jawa dan Luar Jawa. Kesenjangan itu tercermin dari penyebaran sumber daya manusia, industri, perdagangan dan jasa, infrastruktur, irigasi, listrik, pendidikan dan bahkan sektor pertanian. Sektor industri hingga kini 80 persennya masih berada di Jawa. Tentu juga sektor perdagangan dan jasa. Berkembangnya kegiatan ekonomi di JawaBali ditunjang infrastruktur yang relatif lebih baik, seperti jalan raya, pelabuhan dan 
bandara serta ketersediaan energi listrik. Jawa masih menjadi episentrum ekonomi nasional yang secara simbolik terlihat dari pertumbuhan sektor finansial.

\section{METODOLOGI PENELITIAN}

Penelitian ini dirancang sebagai penelitian kuantitatif. Penelitian kuantitatif, sebagaimana dikemukakan oleh Sugiyono (2012:11) yaitu :

Metode penelitian yang berlandaskan pada filsafat positivisme, digunakan untuk meneliti pada populasi atau sampel tertentu, pengumpulan data menggunakan instrumen penelitian, analisis data bersifat kuantitatif/statistik, dengan tujuan untuk menguji hipotesis yang telah ditetapkan.

Penelitian ini dilakukan untuk mengetahui pengaruh pembangunan sumber daya manusia, dan pertumbuhan ekonomi terhadap tingkat kemiskinan di Indonesia berdasarkan kewilayahan Jawa-Luar Jawa dan kewilayahan berdasarkan perbedaan sektor perekonomian terbesar.

Unit analisis dari penelitian ini adalah provinsi di Indonesia. Sebanyak 33 provinsi akan diteliti dan dibagi dalam dua kelompok wilayah, yaitu wilayah JawaLuar Jawa dan wilayah yang dikelompokkan berdasarkan struktur ekonomi yaitu sektor lapangan usaha yang mempunyai peranan terbesar dalam membentuk perekonomian suatu wilayah.

Wilayah Jawa terdiri dari enam provinsi antara lain DKI Jakarta, Jawa Barat, Jawa Tengah, Yogyakarta, Jawa Timur, dan Banten. Sedangkan wilayah Luar Jawa terdiri dari dua puluh tujuh provinsi antara lain Aceh, Sumatera Utara, Sumatera Barat, Riau, Jambi, Sumatera Selatan, Bengkulu, Lampung, Kepulauan Bangka Belitung, Kepulauan Riau, Bali, NTB, NTT, Kalimantan Barat, Kalimantan Tengah, Kalimantan Selatan, Kalimantan Timur, Sulawesi Utara, Sulawesi Tengah, Sulawesi Selatan, Sulawesi Tenggara, Gorontalo, Sulawesi Barat, Maluku, Maluku Utara, Papua Barat, dan Papua.

Dalam penelitian ini, wilayah 33 provinsi dibagi dalam lima kelompok sektor berdasarkan lapangan usaha yang mempunyai kontribusi terbesar dalam membentuk PDRB. Sektor-sektor lapangan usaha tersebut antara lain Pertanian; Pertambangan dan Penggalian; Industri Pengolahan dan Konstruksi; Perdagangan, Hotel, dan Restoran; Keuangan dan Jasa-Jasa. Masing-masing provinsi dimasukkan ke dalam salah satu sektor tersebut berdasarkan kontribusi terbesar yang membentuk PDRB di wilayah tersebut.

Jenis data yang digunakan dalam penelitian ini adalah data sekunder yang diperoleh dari dokumen, website, dan publikasi Badan Pusat Statistik Republik Indonesia, serta sumber lain yang terkait dengan penelitian ini. 
Untuk mengumpulkan data dari sumber data, maka peneliti mempergunakan teknik pengumpulan data Dokumentasi. Dokumentasi berasal dari kata document (Bahasa Inggris) yang artinya dokumen, sedangkan dokumen yang berasal dari kata documentum (Bahasa Latin) berarti tertulis atau tercetak yang dapat dipakai sebagai bukti keterangan. Studi dokumentasi merupakan salah satu cara pengumpulan data dengan menggunakan dokumen-dokumen sebagai sumber data.

Dalam penelitian ini data diperoleh dengan cara dokumentasi, yaitu pengumpulan data dilakukan dengan kategori dan klasifikasi data-data tertulis yang berhubungan dengan masalah penelitian dari berbagai sumber antara lain publikasi-publikasi dan website BPS, koran/majalah, berita online dan jurnaljurnal yang terkait dengan penelitian ini.

Alat analisis yang dipakai untuk mengetahui pengaruh variabel pembangunan sumber daya manusia dan pertumbuhan ekonomi terhadap tingkat kemiskinan berdasarkan kewilayahan adalah dengan menggunakan analisis regresi berganda.

Analisis regresi pada dasarnya adalah studi ketergantungan variabel dependen dengan satu atau lebih variabel independen (variabel bebas), dengan tujuan untuk mengestimasi dan/atau memprediksi rata-rata populasi atau nilai rata-rata variabel dependen berdasarkan nilai variabel independen yang diketahui (Gujarati dan Porter, 2010).

Penelitian ini menggunakan metode penelitian kuantitatif dengan menggunakan data panel. Metode data panel merupakan suatu metode yang digunakan untuk melakukan analisis empirik yang tidak mungkin dilakukan jika hanya menggunakan data time series atau cross section saja. Estimasi model yang menggunakan data panel dapat dilakukan dengan tiga metode, yaitu metode kuadrat terkecil (Pooled Least Square), metode efek tetap (fixed effect) dan metode efek random (random effect).

Gujarati (2004:636) menjelaskan bahwa data panel (pooled data) atau yang disebut juga data longitudinal merupakan gabungan antara data cross section dan data time series. Data cross section adalah data yang dikumpulkan dalam satu waktu terhadap banyak individu, sedangkan data time series merupakan data yang dikumpulkan dari waktu ke waktu terhadap suatu individu. Data panel atau pooled data merupakan kombinasi dari data time series dan cross section dengan mengakomodasi informasi baik yang terkait dengan variabel cross section maupun time series.

Berikut ini adalah model persamaan regresi yang digunakan dalam penelitian ini:

a. Model Pengaruh Pembangunan SDM dan Pertumbuhan Ekonomi terhadap Tingkat Kemiskinan di Indonesia. 
$Y_{\text {it }}=\beta_{0}+\beta_{1} \mathrm{IPM}_{\mathrm{it}}+\beta_{2} \mathrm{PE}_{\mathrm{it}}+\varepsilon_{\mathrm{it}}$

Keterangan :

$$
\begin{aligned}
\mathrm{Y} & =\text { tingkat kemiskinan (\%) } \\
\mathrm{IPM} & =\text { Indeks Pembangunan Manusia (\%) } \\
\mathrm{PE} & =\text { pertumbuhan ekonomi }(\%) \\
\beta_{0} & =\text { intersep } \\
\beta_{1-2} & =\text { koefisien regresi } \\
\varepsilon & =\text { error term } \\
\mathrm{i} & =\text { provinsi ke } \mathrm{i}, \mathrm{i}=1,2,3, \ldots, 33 . \\
\mathrm{t} \quad & =\text { tahun ke } \mathrm{t}, \mathrm{t}=1,2,3, \ldots, 5
\end{aligned}
$$

b. Model Perbedaan Tingkat Kemiskinan di Indonesia Berdasarkan Kewilayahan Jawa dan Luar Jawa yang Dipengaruhi oleh Pembangunan SDM dan Pertumbuhan Ekonomi.

$Y_{i t}=\beta_{0}+\beta_{1} I_{P M}+\beta_{2} P_{i t}+\beta_{3} J_{i t}+\varepsilon_{i t}$

Keterangan :

$\mathrm{Y} \quad=$ tingkat kemiskinan (\%)

IPM = Indeks Pembangunan Manusia (\%)

$\mathrm{PE}=$ pertumbuhan ekonomi (\%)

$\mathrm{JL} \quad=$ variabel moderasi kewilayahan (Luar Jawa $=1$; Jawa $=0$ )

c. Model Pengaruh Pembangunan SDM dan Pertumbuhan Ekonomi terhadap Tingkat Kemiskinan di Indonesia Berdasarkan Kewilayahan Jawa dan Luar Jawa.

1) Wilayah Jawa

$$
\begin{aligned}
& Y_{-} J_{i t}=\beta_{0}+\beta_{1} I P M \_J_{i t}+\beta_{2} P E_{-} J_{i t}+\varepsilon_{i t} \\
& \text { Keterangan : } \\
& \text { Y_J = tingkat kemiskinan provinsi di Jawa (\%) } \\
& \text { IPM_J = Indeks Pembangunan Manusia provinsi di Jawa (\%) } \\
& P E_{-} \mathrm{J}=\text { pertumbuhan ekonomi provinsi di Jawa (\%) }
\end{aligned}
$$

2) Wilayah Luar Jawa

$$
Y \_L_{i t}=\beta_{0}+\beta_{1} I P M \_D_{i t}+\beta_{2} P E L_{-} J_{i t}+\varepsilon_{i t}
$$

Keterangan :

$Y \_$L $\quad$ tingkat kemiskinan provinsi di Luar Jawa (\%)

IPM_LJ = Indeks Pembangunan Manusia provinsi di Luar Jawa (\%)

$\left.P E \_L\right]=$ pertumbuhan ekonomi provinsi di Luar Jawa (\%)

d. Model Pengaruh Pembangunan SDM dan Pertumbuhan Ekonomi Terhadap Tingkat Kemiskinan di Indonesia Berdasarkan Perbedaan Struktur Ekonomi Wilayah. 


$$
\begin{aligned}
& Y_{i t}=\beta_{0}+\beta_{1} \text { IPM }_{i t}+\beta_{2} \text { PE }_{i t}+\beta_{3} \text { DMINING }_{i t}+\beta_{4} \text { DMANUCONS }_{i t}+\beta_{5} \\
& \text { DTRADE }_{i t}+\beta_{6} \text { DFINANSERV }_{i t}+\varepsilon_{i t} \\
& \text { Keterangan : } \\
& \mathrm{Y}=\text { tingkat kemiskinan (\%) } \\
& \text { IPM = Indeks Pembangunan Manusia (\%) } \\
& \mathrm{PE} \quad=\text { pertumbuhan ekonomi (\%) } \\
& \text { DMINING = variabel moderasi sektor pertambangan dan } \\
& \text { penggalian (DMINING = } 1 \text {; lainnya }=0 \text { ) } \\
& \text { DMANUCONS }=\text { variabel moderasi sektor industri pengolahan dan } \\
& \text { konstruksi (DMANUCONS }=1 \text {; lainnya }=0 \text { ) } \\
& \text { DTRADE = variabel moderasi sektor perdagangan, hotel, } \\
& \text { restoran (DTRADE }=1 \text {; lainnya }=0 \text { ) } \\
& \text { DFINANSERV }=\text { variabel moderasi sektor keuangan dan jasa-jasa } \\
& (\text { DFINANSERV }=1 \text {; lainnya }=0 \text { ) }
\end{aligned}
$$

\section{HASIL DAN PEMBAHASAN}

a. Pengaruh Pembangunan SDM dan Pertumbuhan Ekonomi terhadap Tingkat Kemiskinan di Indonesia

Variabel pembangunan SDM menunjukkan pengaruh negatif dan signifikan baik secara simultan maupun parsial terhadap variabel tingkat kemiskinan di Indonesia pada taraf nyata 5 persen yang berarti pembangunan SDM secara signifikan berperan dalam menurunkan tingkat kemiskinan di Indonesia. Hal tersebut sesuai dengan hipotesis yang diajukan bahwa pembangunan SDM berhubungan negatif dan signifikan terhadap tingkat kemiskinan yang mana jika kualitas SDM meningkat maka akan menurunkan tingkat kemiskinan.

Nilai koefisien regresi yang diperoleh sebesar $-1,56$ dengan probabilitas ( $p_{\text {_value }}$ 0,00 yaitu signifikan pada taraf nyata 5 persen artinya jika nilai IPM naik 1 persen maka tingkat kemiskinan di Indonesia akan turun 1,56 persen, ceteris paribus. Hal itu mengindikasikan bahwa pembangunan SDM sangat berpengaruh terhadap penurunan tingkat kemiskinan di Indonesia. Dilihat dari nilai koefisien regresi tersebut turunnya tingkat kemiskinan lebih besar 1,5 kali dari naiknya nilai IPM, ceteris paribus.

Hasil penelitian ini sejalan dengan penelitian Suliswanto (2010) yang menyatakan bahwa secara simultan dan parsial IPM berpengaruh negatif dan signifikan pada $\alpha 5 \%$ terhadap variabel kemiskinan. Hal ini juga senada dengan pendapat Lanjouw, dkk. (2011) yang menyatakan pembangunan manusia di Indonesia identik dengan pengurangan kemiskinan. Pembangunan 
fasilitas pendidikan dan kesehatan yang murah sangat membantu masyarakat miskin dalam meningkatkan produktivitas yang pada gilirannya akan meningkatkan pendapatan dan terlepas dari jurang kemiskinan.

Variabel pertumbuhan ekonomi menunjukkan pengaruh positif dan signifikan baik secara simultan maupun parsial terhadap variabel tingkat kemiskinan di Indonesia pada taraf nyata 5 persen yang berarti pertumbuhan ekonomi bergerak searah dengan tingkat kemiskinan. Hal menunjukkan jika pertumbuhan ekonomi meningkat maka tingkat kemiskinan di Indonesia juga meningkat. Meskipun positif dan signifikan tetapi koefisien variabel pertumbuhan ekonomi kecil yaitu hanya sebesar 0,08 .

Hal tersebut berbeda dengan hipotesis yang diajukan yaitu pertumbuhan ekonomi berpengaruh negatif dan signifikan terhadap tingkat kemiskinan di Indonesia. Nilai koefisien regresi yang diperoleh sebesar 0,08 dengan probabilitas ( $p_{\text {_value }}$ ) 0,03 yang signifikan pada taraf nyata 5 persen artinya jika nilai pertumbuhan ekonomi naik 1 persen maka tingkat kemiskinan di Indonesia akan ikut naik sebesar 0,08 persen, ceteris paribus.

Hal tersebut terjadi dimungkinkan karena kesenjangan ekonomi di Indonesia dalam kurun waktu yang sama mengalami peningkatan. Dibuktikan dengan peningkatan koefisien Gini Indonesia dari semula tahun 2009 sebesar 0,37 menjadi 0,413 pada tahun 2013. Sehingga syarat kecukupan seperti yang dinyatakan Siregar dan Wahyuniarti (2007) tidak terpenuhi yaitu pertumbuhan ekonomi dapat efektif mengurangi tingkat kemiskinan jika menyebar di setiap golongan, termasuk golongan penduduk miskin.

Hasil penelitian tersebut senada dengan penelitian Triariani (2013) yang menunjukkan pertumbuhan ekonomi berpengaruh positif terhadap jumlah penduduk miskin. Karakteristik kemiskinan di Kabupaten Berau antara lain ketidakmampuan memenuhi kebutuhan dasar, ketidakmampuan menjangkau sumber daya sosial dan ekonomi, mudah jatuh dalam kemiskinan (rentan) akibat berbagai resiko. Menurut Triariani (2013), karakteristik kemiskinan inilah yang mengakibatkan jumlah penduduk miskin Kabupaten Berau cenderung bertambah seiring dengan kenaikan pertumbuhan ekonomi.

b. Perbedaan Tingkat Kemiskinan antara Wilayah Jawa dengan Luar Jawa yang Dipengaruhi oleh Pembangunan SDM dan Pertumbuhan Ekonomi

Variabel pembangunan SDM dan pertumbuhan ekonomi hasilnya sama dengan poin (a) yang mana kedua variabel signifikan mempengaruhi tingkat kemiskinan pada taraf 5 persen baik secara simultan maupun secara parsial tetapi dengan arah yang berlawanan. Untuk variabel pembangunan SDM berpengaruh negatif dengan nilai koefisien regresi $-1,56$ sedangkan variabel 
pertumbuhan ekonomi berpengaruh positif dengan dengan nilai koefisien regresi 0,08 .

Variabel moderasi kewilayahan Jawa - Luar Jawa mempunyai nilai koefisien regresi $-0,16$ dengan tingkat signifikansi sebesar 0,945 yang mana lebih besar dari a 5 persen berarti tidak signifikan sehingga dapat dikatakan setelah peneliti mengontrol model persamaan dengan variabel moderasi kewilayahan Jawa-Luar Jawa hasil estimasi analisis variabel pembangunan SDM dan pertumbuhan ekonomi adalah konsisten yang mana variabel pembangunan SDM berpengaruh negatif dan signifikan dan variabel pertumbuhan ekonomi berpengaruh positif dan signifikan. Variabel yang paling berpengaruh tetap variabel pembangunan SDM.

Hasil penelitian ini dapat dikatakan tingkat kemiskinan Indonesia yang dipengaruhi oleh pembangunan SDM dan pertumbuhan ekonomi tidak berbeda secara signifikan antara Jawa dengan Luar Jawa. Hasil ini tidak sejalan dengan hipotesis awal yang menduga terdapat perbedaan yang signifikan antara tingkat kemiskinan di Jawa dan Luar Jawa. Hal ini terjadi dimungkinkan karena perbedaan kemiskinan yang mencolok dapat lebih terlihat pada cakupan wilayah yang lebih kecil, misalnya antara perkotaan dan pedesaan, atau antara pusat wilayah dengan pinggiran.

Seperti yang dinyatakan Nepote dan Ocelli (2004) bahwa relasi antara dunia maju (pusat) dan dunia terbelakang (pinggiran) bukan hubungan simbiosis mutualisme. Wilayah pinggiran tidak memiliki kekuatan yang cukup untuk memperjuangkan kepentingannya, sebaliknya pusat terus memaksakan kepentingannya kepada pinggiran yang berujung pada eksploitasi pusat terhadap pinggiran. Penelitian Prasetyia, Wulandari, dan Hutama (2011) juga menyatakan bahwa pertumbuhan ekonomi yang terjadi sesungguhnya terdapat di daerah perkotaan, padahal sebagian besar penduduk miskin berada di pedesaan.

Oleh karena itu, perbedaan tingkat kemiskinan di wilayah Jawa - Luar Jawa tidak terlihat terlalu berbeda karena masing-masing wilayah tersebut memiliki daerah perkotaan dan perdesaan atau daerah pusat dan daerah pinggiran. Sehingga jika dirata-rata tingkat kemiskinan di wilayah Jawa dan Luar Jawa tidak terlalu jauh berbeda yaitu masing-masing sebesar 11,27 persen dan 13,99 persen.

c. Pengaruh Pembangunan SDM dan Pertumbuhan Ekonomi terhadap Tingkat Kemiskinan di Indonesia Berdasarkan Kewilayahan Jawa dan Luar Jawa.

1) Wilayah Jawa 
Dalam model ketiga pada wilayah Jawa, secara simultan variabel pembangunan SDM dan pertumbuhan ekonomi menunjukkan pengaruh negatif dan signifikan terhadap variabel tingkat kemiskinan pada taraf nyata 5 persen yang berarti pembangunan SDM dan pertumbuhan ekonomi berperan secara bersama-sama dalam menurunkan tingkat kemiskinan di wilayah Jawa.

Secara parsial variabel pembangunan SDM berpengaruh negatif dan signifikan pada taraf nyata 5 persen yang berarti variabel pembangunan SDM secara parsial berperan dalam menurunkan tingkat kemiskinan di wilayah Jawa. Hal tersebut sesuai dengan teori yang ada bahwa pembangunan SDM berhubungan negatif dan signifikan terhadap tingkat kemiskinan yang mana jika kualitas SDM meningkat maka akan menurunkan tingkat kemiskinan.

Nilai koefisien regresi yang diperoleh sebesar $-1,11$ dengan probabilitas (p_value) 0,00 yaitu signifikan pada taraf nyata 5 persen artinya jika nilai IPM naik 1 persen maka tingkat kemiskinan di Jawa akan turun 1,11 persen, ceteris paribus. Hal itu mengindikasikan bahwa pembangunan SDM sangat berpengaruh terhadap penurunan tingkat kemiskinan di Jawa. Dilihat dari nilai koefisien regresi tersebut turunnya tingkat kemiskinan akan lebih besar dibanding dengan naiknya nilai IPM, ceteris paribus.

Hasil penelitian ini sejalan dengan penelitian Suliswanto (2010) yang menyatakan bahwa secara simultan dan parsial IPM berpengaruh negatif dan signifikan pada $\alpha 5 \%$ terhadap variabel kemiskinan. Hal ini juga senada dengan pendapat Lanjouw, dkk. (2011) yang menyatakan pembangunan manusia di Indonesia identik dengan pengurangan kemiskinan. Pembangunan fasilitas pendidikan dan kesehatan yang murah sangat membantu masyarakat miskin dalam meningkatkan produktivitas yang pada gilirannya akan meningkatkan pendapatan dan terlepas dari jurang kemiskinan.

Variabel pertumbuhan ekonomi menunjukkan pengaruh negatif tetapi tidak signifikan. Hasil tersebut menunjukkan variabel pertumbuhan ekonomi secara parsial berperan dalam menurunkan tingkat kemiskinan di wilayah Jawa walaupun pengaruhnya tidak signifikan. Hal tersebut bisa terjadi karena syarat pertumbuhan ekonomi menyebar di semua golongan, terutama golongan bawah tidak terpenuhi. Pertumbuhan ekonomi belum mampu menyentuh di segala sektor, khususnya sektorsektor padat karya dimana banyak masyarakat miskin bekerja. 
Hasil tersebut sama dengan penelitian Prasetyia,Wulandari, dan Hutama (2011) yang menyatakan pertumbuhan ekonomi memiliki pengaruh negatif dan tidak signifikan terhadap penurunan jumlah penduduk miskin. Secara empiris disebabkan belum adanya pemerataan hasil dari pertumbuhan ekonomi, karena lebih banyak dirasakan oleh penduduk perkotaan padahal kebanyakan penduduk miskin berada di pedesaan.

2) Wilayah Luar Jawa

Dalam model ketiga pada wilayah Luar Jawa, secara simultan variabel pembangunan SDM dan pertumbuhan ekonomi menunjukkan pengaruh yang signifikan tetapi dengan arah yang berbeda terhadap variabel tingkat kemiskinan pada taraf nyata 5 persen yang berarti pembangunan SDM dan pertumbuhan ekonomi berperan secara bersamasama dalam menurunkan tingkat kemiskinan di wilayah Luar Jawa.

Secara parsial variabel pembangunan SDM berpengaruh negatif dan signifikan pada taraf nyata 5 persen yang berarti pembangunan SDM di wilayah Luar Jawa secara signifikan berperan dalam menurunkan tingkat kemiskinan. Hasil ini sama dengan hasil penelitian di wilayah Jawa pada poin (1) diatas, yang berbeda adalah nilai koefisien regresinya.

Nilai koefisien regresi yang diperoleh sebesar $-1,64$ dengan probabilitas ( $p \_$value) 0,00 yaitu signifikan pada taraf nyata 5 persen artinya jika nilai IPM naik 1 persen maka tingkat kemiskinan di Luar Jawa akan turun 1,64 persen, ceteris paribus. Hal itu mengindikasikan bahwa pembangunan SDM sangat berpengaruh terhadap penurunan tingkat kemiskinan di Luar Jawa. Dilihat dari nilai koefisien regresi tersebut turunnya tingkat kemiskinan akan lebih besar 1,64 kali dibanding dengan naiknya nilai IPM, ceteris paribus.

Variabel pertumbuhan ekonomi menunjukkan pengaruh positif dan signifikan pada taraf nyata 5 persen yang berarti pertumbuhan ekonomi di wilayah Luar Jawa secara signifikan memicu meningkatnya tingkat kemiskinan tetapi dengan nilai koefisien yang kecil yaitu hanya sebesar 0,08 . Hal tersebut terjadi dimungkinkan karena terjadi kesenjangan ekonomi di Luar Jawa yang terbukti dengan tidak meratanya petumbuhan ekonomi. Pertumbuhan ekonomi di wilayah Luar Jawa ada yang bergerak negatif yaitu paling rendah $-5,51$ persen dan ada yang melejit cepat paling tinggi yaitu 28,47 persen. Hasil penelitian tersebut senada dengan penelitian Triariani (2013) yang menunjukkan pertumbuhan ekonomi berpengaruh positif terhadap jumlah penduduk miskin. 
Perbandingan hasil output pengolahan untuk wilayah Jawa dan Luar Jawa menunjukkan bahwa pengaruh pembangunan SDM dan pertumbuhan ekonomi terhadap kemiskinan di Indonesia berbeda antara wilayah Jawa dengan Luar Jawa. Pengaruh pembangunan SDM terhadap tingkat kemiskinan di Jawa negatif 1,11 sedangkan di Luar Jawa negatif 1,64 dan keduanya signifikan pada taraf 5 persen. Hasil penelitian ini sejalan dengan penelitian Suliswanto (2010) dan senada dengan pendapat Lanjouw, dkk. (2011) yang menyatakan pembangunan manusia di Indonesia identik dengan pengurangan kemiskinan, seperti penjelasan pada poin (a) atau model regresi pertama.

Dalam hasil penelitian ini untuk variabel pembangunan SDM yang berbeda adalah besaran koefisien regresinya yang mana pembangunan SDM di wilayah Luar Jawa mempunyai koefisien regresi lebih besar dibandingkan wilayah Jawa yang berarti variabel pembangunan SDM berpengaruh lebih besar di wilayah Luar Jawa. Pengaruh pertumbuhan ekonomi terhadap tingkat kemiskinan di Jawa negatif 1,16 tetapi tidak signifikan, sedangkan di Luar Jawa positif 0,08 dan signifikan pada taraf 5 persen tetapi nilai koefisien tersebut kecil.

Hal ini sejalan dengan hipotesis awal yang menduga bahwa pengaruh pembangunan SDM dan pertumbuhan ekonomi terhadap tingkat kemiskinan di Indonesia berbeda antara wilayah Jawa dengan Luar Jawa.

d. Pengaruh Pembangunan SDM dan Pertumbuhan Ekonomi Terhadap Tingkat Kemiskinan di Indonesia Berdasarkan Perbedaan Struktur Ekonomi Wilayah.

Model keempat pada penelitian ini akan melihat pengaruh pembangunan SDM, pertumbuhan ekonomi dan perbedaan struktur ekonomi wilayah terhadap tingkat kemiskinan di Indonesia. Disini peneliti menambahkan variabel moderasi sektor untuk melihat perbedaan tingkat kemiskinan antar wilayah yang terbagi berdasarkan sektor perekonomian terbesar. Hasil penelitian menunjukkan secara bersama-sama variabel pembangunan SDM, pertumbuhan ekonomi, dan variabel moderasisektor berpengaruh signifikan terhadap tingkat kemiskinan di Indonesia pada taraf nyata 5 persen.

Secara individual, variabel pembangunan SDM menunjukkan pengaruh negatif dan signifikan terhadap variabel tingkat kemiskinan di Indonesia pada taraf nyata 5 persen yang berarti pembangunan SDM berperan dalam menurunkan tingkat kemiskinan di Indonesia. Variabel pembangunan SDM berhubungan negatif dengan tingkat kemiskinan di Indonesia yang artinya jika kualitas SDM meningkat maka akan menurunkan tingkat kemiskinan di 
Indonesia. Nilai koefisien regresi yang diperoleh sebesar $-1,56$ dengan probabilitas (p_value) 0,00 yaitu signifikan pada taraf nyata 5 persen artinya jika nilai IPM naik 1 persen maka tingkat kemiskinan di Indonesia akan turun 1,56 persen, ceteris paribus. Hal itu mengindikasikan bahwa IPM berpengaruh secara nyata terhadap penurunan tingkat kemiskinan di Indonesia.

Hasil penelitian ini sejalan dengan penelitian Suliswanto (2010) yang menyatakan bahwa secara simultan dan parsial IPM berpengaruh negatif dan signifikan pada $\alpha 5 \%$ terhadap variabel kemiskinan. Hal ini juga senada dengan pendapat Lanjouw, dkk. (2011) yang menyatakan pembangunan manusia di Indonesia identik dengan pengurangan kemiskinan. Pembangunan fasilitas pendidikan dan kesehatan yang murah sangat membantu masyarakat miskin dalam meningkatkan produktivitas yang pada gilirannya akan meningkatkan pendapatan dan terlepas dari jurang kemiskinan.

Variabel pertumbuhan ekonomi secara parsial menunjukkan pengaruh positif dan signifikan terhadap variabel tingkat kemiskinan di Indonesia pada taraf nyata 5 persen yang berarti naiknya pertumbuhan ekonomi akan mengakibatkan tingkat kemiskinan di Indonesia. Nilai koefisien regresi yang diperoleh sangat kecil yaitu sebesar 0,08 dengan probabilitas ( $p \_$value) 0,03 yang signifikan pada taraf nyata 5 persen artinya jika nilai pertumbuhan ekonomi naik 1 persen maka tingkat kemiskinan di Indonesia akan ikut naik sebesar 0,08 persen, ceteris paribus.

Hal tersebut terjadi karena kesenjangan ekonomi di Indonesia dalam kurun waktu yang sama mengalami peningkatan. Dibuktikan dengan peningkatan koefisien Gini Indonesia dari semula tahun 2009 sebesar 0,37 menjadi 0,413 pada tahun 2013. Sehingga syarat kecukupan seperti yang dinyatakan Siregar dan Wahyuniarti (2007) tidak terpenuhi yaitu pertumbuhan ekonomi dapat efektif mengurangi tingkat kemiskinan jika menyebar di setiap golongan, termasuk golongan penduduk miskin.

Hasil penelitian tersebut senada dengan penelitian Triariani (2013) yang menunjukkan pertumbuhan ekonomi berpengaruh positif terhadap jumlah penduduk miskin. Karakteristik kemiskinan di Kabupaten Berau antara lain ketidakmampuan memenuhi kebutuhan dasar, ketidakmampuan menjangkau sumber daya sosial dan ekonomi, mudah jatuh dalam kemiskinan (rentan) akibat berbagai resiko. Menurut Triariani (2013), karakteristik kemiskinan inilah yang mengakibatkan jumlah penduduk miskin Kabupaten Berau cenderung bertambah seiring dengan kenaikan pertumbuhan ekonomi.

Uji parsial menunjukkan variabel pembangunan SDM dan pertumbuhan ekonomi signifikan dalam model sedangkan variabel moderasisektor tidak 
signifikan dalam model sehingga dapat dikatakan setelah peneliti mengontrol model persamaan dengan variabel moderasi sektor atau perbedaan struktur ekonomi wilayah, hasil estimasi analisis variabel pembangunan SDM dan pertumbuhan ekonomi adalah konsisten yang mana variabel pembangunan SDM berpengaruh negatif dan signifikan dan variabel pertumbuhan ekonomi berpengaruh positif dan signifikan. Variabel yang paling berpengaruh tetap variabel pembangunan SDM. Perbedaan struktur perekonomian suatu wilayah tidak berpengaruh terhadap tingkat kemiskinan di Indonesia

Hasil ini tidak sejalan dengan hipotesis awal yang menduga terdapat terdapat perbedaan tingkat kemiskinan yang signifikan antar wilayah yang memiliki perbedaan struktur ekonomi. Dilihat dari data empiris memang secara rata-rata tingkat kemiskinan antar wilayah berdasarkan perbedaan struktur ekonomi mempunyai kemiripan atau hampir sama. Nilai rata-rata tingkat kemiskinan masing-masing wilayah berdasarkan perbedaan struktur ekonomi dikisaran 13-14 persen, seperti terlihat pada output pengolahan dibawah. Oleh karena itu tingkat kemiskinan berdasarkan perbedaan struktur ekonomi wilayah memang tidak berbeda secara signifikan.

Hal ini terjadi dimungkinkan karena perbedaan kemiskinan yang mencolok dapat lebih terlihat pada cakupan wilayah yang lebih kecil, misalnya antara perkotaan dan pedesaan, kawasan dan non kawasan atau antara pusat wilayah dengan pinggiran. Seperti yang dinyatakan Nepote dan Ocelli (2004) dan Prasetyia,Wulandari, dan Hutama (2011). Dalam hal ini dimungkinkan perbedaan struktur ekonomi antar wilayah yang dibentuk berdasarkan struktur ekonomi provinsi di Indonesia belum mampu secara signifikan membedakan perbedaan tingkat kemiskinan karena cakupannya terlalu luas.

Secara berurutan nilai rata-rata tingkat kemiskinan pada wilayahwilayah dengan sektor pembentuk perekonomian terbesarnya pada sektor pertanian 13,15 persen; sektor pertambangan dan penggalian 13,57 persen; sektor industri pengolahan dan konstruksi 13,29 persen; sektor keuangan dan jasa-jasa 13,73 persen; serta sektor perdagangan, hotel dan restoran 14,42 persen. Wilayah dengan sektor pembentuk perekonomian terbesarnya di sektor pertanian memiliki rata-rata tingkat kemiskinan yang lebih rendah dibandingkan dengan sektor lainnya. Hal tersebut sesuai hasil regresi yang mana sektor pertanian menjadi base. Semua koefisien variabel moderasi sektor bernilai positif sehingga dapat dikatakan sektor-sektor lainnya mempunyai rata-rata tingkat kemiskinan yang lebih tinggi dibandingkan dengan sektor pertanian. 


\section{KESIMPULAN}

1. Hasil penelitian menunjukkan bahwa pembangunan SDM dan pertumbuhan ekonomi secara simultan berpengaruh signifikan terhadap tingkat kemiskinan di Indonesia.

2. Pembangunan SDM, pertumbuhan ekonomi dan variabel moderasi Kewilayahan Jawa-Luar Jawa secara simultan berpengaruh signifikan terhadap tingkat kemiskinan di Indonesia.

3. Pengaruh pembangunan SDM dan pertumbuhan ekonomi terhadap tingkat kemiskinan di Indonesia berbeda antara wilayah Jawa dengan Luar Jawa. Hasil tersebut sesuai dengan hipotesis penelitian ini.

4. Hasil penelitian menunjukkan secara simultan variabel pembangunan SDM, pertumbuhan ekonomi, dan kewilayahan berdasarkan struktur ekonomi (variabel moderasi sektor) berpengaruh signifikan terhadap tingkat kemiskinan di Indonesia.

\section{DAFTAR PUSTAKA}

Aimon, Hasdi, 2012. Produktivitas, Investasi Sumber Daya Manusia, Investasi Fisik, Kesempatan Kerja terhadap Kemiskinan dan Pertumbuhan Ekonomi di Indonesia. Jurnal Kajian Ekonomi, Vol 1 No 1, Mei 2012, hal. 209-218.

Arsyad, Lincolin, 1999. Ekonomi Pembangunan, Ed. 3. STIE YKPN BPFE. Yogyakarta.

Badan Pusat Statistik, 2013. Jumlah dan Persentase Penduduk Miskin, Garis Kemiskinan, Indeks Kedalaman Kemiskinan (P1), dan Indeks Keparahan Kemiskinan (P2) Menurut Provinsi, September 2012. http http://bps.go.id/linkTabelStatis/view/id/1489, diakses pada 24 Juni 2015 jam 13:36 WIB.

2015. Indeks Pembangunan Manusia Menurut Provinsi, 1996-2013. http://bps.go.id/linkTableDinamis/view/id/909, diakses pada 24 Juni 2015 jam 13:58 WIB.

Badan Perencanaan Pembangunan Nasional, 2015. Lampiran Peraturan Presiden Republik Indonesia Nomor 2 Tahun 2015 Tentang Rencana Pembangunan Jangka Menengah Nasional (RPJMN) 2015-2019. Buku III Agenda Pembangunan Wilayah. Bappenas. Jakarta.

Gujarati, Damodar N., 2003. Basic Econometrics. The McGraw-Hill Companies. New York. McGraw-Hill Companies. New York.

Gujarati, Damodar N. dan Porter Dawn C, 2010. Dasar-Dasar Ekonometrika Edisi 5 Buku 2. Salemba Empat. Jakarta.

Lanjouw, P., Pradhan M., Saadah F., Sayed H., Sparrow R., 2011. Poverty, Education and Health in Indonesia: Who Benefits from Public Spending?. World Bank Working Paper, No. 2739. World Bank. Washington D.C.

Mishkin, S. Frederic, 2012. Macroeconomics: Policy and Practice, Golbal Edition. Pearson. New York. 
Nasikun, 2001. Isu dan Kebijakan Penanggulangan Kemiskinan. Diktat Mata Kuliah. Magister Administrasi Publik. Universitas Gadjah Mada. Yogyakarta.

Nepote, D. dan Occelli S., 2004. Beyond Core-Periphery Relationship in the EU Cooperation. Istituto di Ricerche Economico Sociali del Piemonte. Torino.

Prasetyia, Ferry, Wulandari Farah, dan Hutama Ri Setia, 2011. Pengeluaran Sektor Publik, Pertumbuhan Ekonomi dan Kemiskinan Indonesia. Jurnal Ekonomi dan Pembangunan Indonesia, Vol XI No 2, 2011, hal .99-116.

Siregar, Hermanto dan Wahyuniarti Dwi, 2007. Dampak Pertumbuhan Ekonomi Terhadap Penurunan Jumlah Penduduk Miskin. http://pse.litbang.deptan.go.id/ind/pdffiles/PROS_2008_MAK3.pdf. Diakses tanggal 3 Juni 2015.

Sugiyono, 2012. Metode Penelitian Bisnis. Pusat Bahasa Depdiknas. Bandung.

Sukirno, Sadono, 1996. Makroekonomi Teori Pengantar. PT Raja Grafindo Persada. Jakarta. 2000. Ekonomi Pembangunan (Edisi Kedua). Kencana. Jakarta.

Suliswanto, Muhammad Sri Wahyudi, 2010. Pengaruh Produk Domestik Bruto (PDB) dan Indeks Pembangunan Manusia (IPM) terhadap Angka Kemiskinan di Indonesia. Jurnal Ekonomi Pembangunan, Vol 8 No 2, Desember 2010, hal. 357-366.

Suryawati, Chriswardani, 2005. Memahami Kemiskinan Secara Multidimensional. JMPK, Vol. 08 No.03, September 2005, hal. 121-129.

Triariani, Endah Ernany, 2013. Analisis Pengaruh Pertumbuhan Ekonomi, Jumlah Pengangguran dan Indeks Pembangunan Manusia (IPM) terhadap Jumlah Penduduk Miskin di Kabupaten Berau. Jurnal Ekonomi, Vol. XI, No. 1, Maret 2013, hal. 1-20. 